\title{
German citizenship law and the Turkish diaspora
}

\author{
Susan Willis McFadden*
}

(Received 16 January 2018; accepted 23 March 2018)

\begin{abstract}
People of Turkish ethnicity constitute Germany's largest immigrant group but only a small percentage have naturalized as German citizens This article explores the historical foundation of Turkish migration to Germany and the legislative attempts made by both Germany and Turkey to accommodate these people with one foot in each country. It argues that only by abandoning its long-held prejudice against dual citizenship can Germany increase the naturalization rate of all foreigners in its country, not just those from Turkey.
\end{abstract}

Keywords: dual citizenship; naturalization; nationality; Turkey; Germany

\section{A. Introduction}

On October 31, 1961, the Federal Republic of Germany and the Republic of Turkey signed an agreement to promote the expedited hiring of Turkish citizens for jobs in Germany. ${ }^{1}$ The reason for this: In the late 1950s and early 1960s, the German economy was flourishing - the "economic miracle" (Wirtschaftswunder) — and experiencing a labor shortage. One of the solutions was a series of agreements with countries in North Africa, Southeast Europe and the Balkans for the provision of cheap labor, much of it unskilled and all of it thought by Germany to be temporary in nature-therefore, the euphemism "guest workers" (Gastarbeiter). ${ }^{2}$

Fifty-seven years later, Turks are the largest ethnic minority group in Germany, numbering nearly three million residents; only approximately 246,000 of them hold German citizenship. ${ }^{3}$ This Article focuses on the reasons for this low figure, the steps taken by both German and Turkish governments to deal with this binational population, and the problems that have arisen.

First, a note about terminology. To social scientists, the word "citizenship" can include multiple dimensions: Legal status, rights, political participation, and a sense of belonging. ${ }^{4}$ For our

\footnotetext{
${ }^{*}$ Susan Willis McFadden obtained B.A. in Pomona College, and J.D. in Stanford Law School. Ms. McFadden practices U.S. immigration law in London, England with the firm Gudeon \& McFadden. Email: smcfadden@usvisalawyers.co.uk. An earlier version of this Article was presented to the School of Oriental and African Studies (SOAS), University of London, as a dissertation in partial satisfaction of the requirements for the M.A. in Turkish Studies. All translations from German are by the author. All Internet sources were accessed on January 16, 2018.

${ }^{1}$ Unless otherwise stated, "Germany" refers to the Federal Republic of Germany (FRG) and does not include the German Democratic Republic before that country was subsumed into the FRG on October 3, 1990.

${ }^{2}$ Faruk Şen \& Andreas Goldberg, Türken in Deutschland: Leben zWischen zWei Kulturen [Turks in Germany: LIFE BETWEEN TWO CULTURES] 9 (1994) (stating labor agreements were reached with Italy (1955), Greece (1960), Spain (1960), Turkey (1961), Morocco (1963), Portugal (1964), Tunisia (1965) and Yugoslavia (1968)).

${ }^{3}$ Bevölkerung mit Migrationshintergrund - Ergebnisse des Mikrozensus 2016 [Population with Migration Background Results of the Micro census of 2016], Federal OfFice OF STATISTICs 63 (2016) https://www.destatis.de/DE/Publikationen/ Thematisch/Bevoelkerung/MigrationIntegration/Migrationshintergrund2010220167004.pdf;jsessionid=0646332EA70C5CB B98688BB718A6C657.cae1?_blob=publicationFile [hereinafter Migration].

${ }^{4}$ Irene Bloemraad, et al., Citizenship and Immigration: Multiculturalism, Assimilation, and Challenges to the Nation-State, 34 Ann. Rev. of Soc. 153, 154-56 (2008).
}

(C) 2019 The Author. Published by Cambridge University Press on behalf of the German Law Journal. This is an Open Access article, distributed under the terms of the Creative Commons Attribution licence (http://creativecommons.org/licenses/by/4.0/), which permits unrestricted re-use, distribution, and reproduction in any medium, provided the original work is properly cited. 
purposes, we will speak exclusively of citizenship as legal status. This is an objective and easily measured fact and does not require an inquiry into the subjective aspects of citizenship such as identity and the extent to which a country's citizens feel engaged with their government. Citizenship - for our purposes - is that legal relationship of a person with a country that confers the maximum scope of rights available in that country. These include the rights to remain permanently, to be readmitted after an absence, to inherit and own property, to vote and to hold elective office. The easiest identifier for this category: A citizen is a person eligible for a passport-an internationally recognized travel document that identifies the bearer as a citizen of the issuing country. ${ }^{5}$

\section{B. "We sent for workers, but people came."6}

\section{The genesis of the problem}

When the thousands of Turkish workers moved to Germany, the German government thought that most would be men, who would work there for a few years, send money back home, and then return to Turkey with cash and new skills. Because the government believed their stay would be temporary, no attempt was made to integrate them into German society. Many lived in dormitories provided by their employers, where they remained among themselves. They were not encouraged to learn the German language beyond the bare minimum required to carry out their jobs.

In October 1973, the embargo by the Organization of Petroleum Exporting Countries set off a worldwide recession from which Germany was not exempt. The worker agreement with Turkey was not renewed and the German government offered incentives to workers willing to move back to their countries of origin. any Turks chose to remain, however. ${ }^{7}$ They began to regard their stay in Germany as something long term, even if Turkey remained "home." Many of the workers brought wives and families to Germany. By 2002, only one-third of the Turks in Germany had arrived as guest workers, approximately fifty-three percent of Turkish residents had immigrated to Germany under family reunification visas, and seventeen percent were their descendants born in Germany. ${ }^{8}$

As the population in Germany of Turkish immigrants and their families increased, it became clear that German citizenship law was keeping many of them permanently "foreign," by making accession to German citizenship tremendously difficult. The low rate at which Turks naturalized raised concerns as to whether they were being prevented from fully integrating into German society and the body politic. As will be seen, the two major barriers to Turks becoming German citizens were the German prohibition of dual or multiple citizenship, and the failure to extend birthright citizenship to the German-born children of immigrants. ${ }^{9}$

Over the years, German governments and Turkish organizations in Germany tried addressing the perceived problem caused by the large number of Turkish heritage residents who had not taken on German citizenship. Generally, the Germans saw the Turks' failure to naturalize as demonstrating a lack of attachment to Germany, while Turks maintained that it was the requirement of renouncing their Turkish citizenship that was the cause of the low naturalization rate.

\footnotetext{
${ }^{5}$ There are, of course, other travel documents issued by a country or organization — such as the Red Cross-that are recognized for international travel but contain a disclaimer of nationality. For a history of the development of the passport, see Kenneth Diplock, Passports and Protection in International Law, 32 TransaCtions OF THE Grotius Soc'y 42, 44-52 (1946).

${ }^{6}$ Wir riefen Arbeitskräfte, und es kamen Menschen, DER SPIEGEL (Oct. 30, 2011), http://www.spiegel.de/fotostrecke/ gastarbeiter-wir-riefen-arbeitskraefte-und-es-kamen-menschen-fotostrecke-74565-2.html (quoting Max Frisch).

${ }^{7}$ Statistisches Bundesamt, DATENREPORT 46 (1999), https://www.destatis.de/DE/Publikationen/Datenreport/Downloads/ Datenreport1999.pdf?_blob=publicationFile (specifying that the end of the labor agreements and offers of assistance to return resulted in decreases of the foreign-born population in Germany during several years in the mid-1970s and 1980s).

${ }^{8}$ Merih Anil, Explaining the Naturalization Practices of Turks in Germany in the Wake of the Citizenship Reform of 1999, 33 J. OF ETHNic \& Migration STUd. 1363, 1365 (2007).

${ }^{9}$ As will be seen below, even before the 1999 reform exceptions to the prohibition against multiple citizenship were made for the benefit of citizens of other EU countries and of Switzerland.
} 


\section{Citizenship: blood and soil}

There are two primary ways in which citizenship is acquired at birth-jus sanguinis and jus soli. Jus sanguinis refers to acquisition of citizenship through descent: Children, regardless of where they are born, acquire at birth the citizenship of a parent. Jus soli is the doctrine that children acquire the citizenship of the country in which they are born. Each country legislates its own requirements for citizenship. The European Convention on Nationality, for example, provides, "[e]ach State shall determine under its own law who are its nationals," and requires all signatory countries to accept others' law on the subject insofar as consistent with generally-recognized international law. ${ }^{10}$

Most countries operate a hybrid system conferring citizenship on some children born within their borders, often subject to requirements about the legality or length of the parents' presence in the country at the time of the child's birth and supplemented by granting citizenship to some children born to citizen parents outside the country itself. Countries' attitudes towards granting citizenship based on either jus sanguinis or jus soli depend greatly upon whether they are traditionally sources or recipients of immigrants. ${ }^{11}$

At one extreme, Ireland is the epitome of a system for which jus sanguinis is the most important factor. The Republic of Ireland grants citizenship to persons who have a single great-grandparent born on the island of Ireland, subject to registration requirements. ${ }^{12}$ This is to be expected from a country that has seen millions of its sons and daughters emigrate: There is an advantage in binding those people and their descendants to the home country through provision of citizenship for the children and grandchildren of emigrants. Emigrants are not only a source of remittances from foreign work, which can help support the relatives at home, but they and their descendants can act as a friendly lobby in the receiving countries. ${ }^{13}$

The United Kingdom has a mixed system, extending British citizenship to children born in the UK whose parents have a settled immigration status, but to just one generation of the children of UK citizen parent(s) who were themselves born abroad. ${ }^{14}$ The United States-on the opposite end from Ireland on the jus soli/jus sanguinis spectrum-grants under its constitution citizenship to almost everyone born on American soil, regardless of the parents' citizenship or immigration status. ${ }^{15}$ Citizenship for children born to US citizen parents outside the country is created by statute and has customarily required that the US citizen parent is physically present in the United States for a certain length of time before the child's birth in order for citizenship to be transmitted. ${ }^{16}$

\footnotetext{
${ }^{10}$ Convention on Nationality, Nov. 6, 1997, 1997 O.J. (C 2) 3, https://rm.coe.int/168007f2c8 [hereinafter Convention on Nationality].

${ }^{11}$ Albert Kraler, The Legal Status of Immigrants and Their Access to Nationality, in Migration And CitizenshiP: LeGAL Status, Rights and Political Participation 44-45 (Rainer Bauböck ed., 2006).

${ }^{12}$ Qualifications for Citizenship by Birth or Decent, DEP'T OF JUSTICE AND EQUAL. IRISH NATURALISATION AND IMMIGRATION SERV., http://www.inis.gov.ie/en/INIS/Pages/citizenship-greatgrandparent-born-ireland (stating that in 2004 Irish voters overwhelmingly approved (seventy-nine percent in favor, twenty-one percent against) the ending of birthright citizenship for all babies born in Ireland, after claims that the liberal jus soli, unique in the EU, was being used to create Irish citizenship for babies whose parents had no ties to Ireland); Angelique Chrisafis, Ireland tightens ring of steel around fortress Europe, The Guardian (June 14, 2004), https://www.theguardian.com/politics/2004/jun/14/eu.politics; TwENTY-SEVENTH AMENDMENT of THE Constitution ACт 2004 (Ir.), http://www.irishstatutebook.ie/eli/2004/ca/27/enacted/en/html (This is a logical result from an ethnically homogeneous immigrant-sending nation).

${ }^{13}$ The Irish diaspora in the United States is the very archetype of a powerful immigrant lobby. See, e.g., PETER ANDERSON, The Global Politics of Power, Justice and Death 30-31 (2005).

${ }^{14}$ British Nationality Act 1981, c. 61, §3(1), (3) http://www.legislation.gov.uk/ukpga/1981/61/section/3.

${ }^{15}$ U.S. CONST. AMEND. XIV, $\$ 1$ ("All persons born or naturalized in the United States, and subject to the jurisdiction thereof, are citizens of the United States.") (exempting those persons whose parents were at the time of the child's birth not "subject to the jurisdiction" of the United States, such as the children of some diplomats).

${ }^{16}$ Immigration and Nationality Act $\$ 301,8$ U.S.C. $\$ 1401$ (1952).
} 


\section{German law before 2000 and the problems it caused}

Traditionally, both Turkey and Germany are countries of emigration, not immigration, and as will be seen below, both countries' laws have traditionally defined citizenship in terms that suggest that only persons with a certain ethnicity are real citizens. Until the new citizenship law came into effect on January 1, 2000, the FRG was still operating under the same law of citizenship and nationality-occasionally amended — that governed since 1913. Under that law, the primary route to becoming a German citizen was to have at least one German parent. The limitation of German birthright citizenship to transmission exclusively through descent therefore well predates Nazism, although it is often misunderstood as a product of the racist Nazi era. ${ }^{17}$

Before January 1, 2000, children born in Germany to non-Germans-no matter how long the parents' stay had been-had no right to German citizenship. By contrast, under the German constitution, the Basic Law, citizenship was offered to all persons descended from members of the German Volk who were living in Germany in 1937:

A German in the sense of this Basic Law is, to the extent not otherwise regulated by law, a person who possesses German citizenship [Staatsangehörigkeit] or a refugee or exiled person of German nationality [Volkszugehörigkeit], or his spouse or descendant, who was living in the area of the German Empire as constituted on 31 December $1937 .^{18}$

The word Volk has acquired through its use by the National Socialists a taint that was not always present. The idea of the German nation as "a romantically inspired community of common ethnic and cultural descent" has its roots in the early $19^{\text {th }}$ century, and this still-existing frame of mind makes it difficult for many Germans to regard outsiders as real Germans. ${ }^{19}$ These people see their country as a nation united by a common consciousness which an outsider cannot join any more than a long-term boarder can become a blood relative merely by years of living in the family home. ${ }^{20}$

Over the years, the German government has often declared that "Germany is not a country of immigration." Reality, however, has overtaken dogma. By the time of the 2015 micro census, twenty-one percent of all German residents had a migration background-that is, either they or at least one of their parents were not German citizens from birth. ${ }^{21}$

The major difficulty for Turks interested in German citizenship is the German aversion to multiple citizenship because Turks are disinclined to renounce their birth citizenship to become

\footnotetext{
${ }^{17}$ See, e.g., Two Unamalgamated Worlds, THE Economist (Apr. 3, 2008), https://www.economist.com/briefing/2008/04/03/ two-unamalgamated-worlds ("Even six decades after Hitler, Germany has not sloughed off the idea that Germanness is a matter of blood rather than of culture or allegiance."); AYHAN KAYA, Citizenship and the Hyphenated Germans: GermanTurks, in Citizenship in a Global World: European Questions AND Turkish Experiences 219,219 (Emin F. Keyman \& Ahmet İçduygu eds., 2005) (referring to jus sanguinis and "the Nazi policies with which it came to be tragically associated").

${ }^{18}$ GrundGesetz FÜR Die Bundesrepublik Deutschland [GG] [Basic Law] art. 116(1), http://www.gesetze-im-internet. de/bundesrecht/gg/gesamt.pdf (leading up to the 1999 law, more than one speaker pointed out the unfairness of denying dual citizenship to migrants in Germany while "practically forcing it," through the Basic Law, on German ethnics in Eastern Europe); see, e.g., Bundestag debate at 3441 (May 7, 1999) (statement of Rep. Ulla Jelpke) http://dip21.bundestag.de/ $\operatorname{dip} 21 /$ btp/14/14040.pdf.

${ }^{19}$ Simon Green, Beyond Ethnoculturalism? German Citizenship in the New Millennium, 9 GER. POL. 105, 106 (2000); see also Rogers Brubaker, Citizenship and Nationhood in France And Germany 9 (1992); for a discussion of the impact of the Romantik Movement upon German law in general and the German Civil Code of 1900 in particular, see SG Gale, A Very German Legal Science: Savigny and the Historical School, 18 STAN. J. OF INT'L L. 123 (1982).

${ }^{20}$ But see JÜRgen Gerdes et AL., "We are all 'Republican' now": The Politics of Dual Citizenship in Germany, in DuAL Citizenship in Europe: From Nationhood to Societal Integration 47, 56-57 (Thomas Faist ed., 2007) (“[T]he German concept of nation has undergone drastic changes" post-World War II and the dislike of naturalization and multiple citizenship is explainable by other factors).

${ }^{21}$ Migration, supra note 3, at 4, 7 (The micro census is an annual survey of representative households in Germany amounting to one percent of the total number of German residents, supplementing the general census performed every decade. Explanation of the methodology at https://www.destatis.de/DE/ZahlenFakten/GesellschaftStaat/Bevoelkerung/Mikrozensus.html).
} 
German. The avoidance of multiple citizenship is not a uniquely German peculiarity-historically, international law disfavored dual citizenship due to the possibility that the citizen could be caught in a conflict of loyalties between his two countries. Until 1981, Turkish law also prohibited multiple citizenships for its citizens.

Since 1913, the general rule has been that a foreigner wishing to acquire German citizenship through naturalization must forfeit his previous citizenship, unless he can show extraordinary circumstances that would make the loss of that citizenship particularly burdensome or even impossible. $^{22}$ Similarly, a German citizen who naturalizes in a foreign country loses his German citizenship unless, before naturalizing, he obtains a "permission to retain" (Beibehaltungsgenehmigung) based upon a similar showing of hardship. ${ }^{23}$ Importantly, German citizens living in Germany were exempt from this prohibition, which became known as the "domestic exemption" (Inlandsklausel). ${ }^{24}$

\section{Turkish innovations}

The current Turkish Constitution, in language consistent with the 1924 and 1961 versions, provides that "[e]veryone bound to the Turkish State through the bond of citizenship is a Turk." 25 This formulation disregards the fact that there are Turkish citizens who would not self-identify as "Turks," ${ }^{26}$ and echoes the early history of the Republic which was marked by numerous attempts to create an ethnically homogeneous country.

In 1981, Turkey, aware of its identity as an emigrant country, changed its nationality law to allow-for the first time - the possession of multiple citizenships. ${ }^{27}$ Provision is made for the easy reacquisition of citizenship by Turks who renounce their citizenship in order to naturalize in a foreign country-they can reacquire Turkish citizenship without any period of residence in Turkey. ${ }^{28}$ A professor at Ankara University's law faculty states that the allowance of multiple citizenships was enacted expressly in response to the attempts by host countries to integrate Turkish-origin residents by offering them citizenship.

\footnotetext{
${ }^{22}$ Staatsangehörigkeitsgesetz [STaG] [Nationality Act], July 22, 1913, REICHSGESETZBLATT [RGBl] at $\$ 10(1)(4)($ requirement to lose or renounce), $₫ 12(1)$ (exceptions to the requirement).

${ }^{23}$ For the current law, see StaG $\$ 17(1)(2)$ (loss of citizenship upon naturalization in a foreign country), \& $\$ 25$ (explaining conditions under which permission to naturalize while retaining German citizenship will be granted), http://dip21.bundestag. de/dip21/btd/18/107/1810788.pdf; see also Barbara Pusch, Dual citizenship in the transnational German-Turkish space: Notes from Germany, IPC-Mercator POL. BRIEF 2 (Feb. 2015), http://ipc.sabanciuniv.edu/en-old/wp-content/uploads/2015/02/ Barbara-push-feb_son1.pdf (stating naturalization with dual citizenship has long been possible for nationals of EU countries and Switzerland where allowed to Germans on a reciprocal basis).

${ }^{24}$ Verlust der deutschen Staatsangehörigkeit bei Wiedereinburgerung durch ausländische Staaten, [Loss of German citizenship by reacquisition of foreign citizenship] DRUCKSACHE [DOCUMENT] 15/5006 at 2 (explaining the process in the German government's answer to a CDU/CSU Parliamentary question); bundestag publications before 18 October 2005 are available at http:// dip.bundestag.de.

${ }^{25}$ TURK. CONST. part 2, c. 4, art. 66, https://global.tbmm.gov.tr/docs/constitution_en.pdf; for the 1924 and 1961 provisions, see, respectively, Edward M. Earle, The New Constitution of Turkey, 40 PoL. SCI. Q. 73, 98 (Mar. 1925) (art. 88), http://www. anayasa.gen.tr/1961 constitution-text.pdf (part 2, \$4, art. 54); for a historical overview, see Ahmet Içduygu, et al., What is the Matter with Citizenship? A Turkish Debate, 35 Middle E. STud. 187, 192-97 (1999).

${ }^{26}$ Zeynep Kadirbeyoğlu, Country Report: Turkey, EUDO CiTIZENSHIP OBSERVATORY 3 (2012), http://www.foyer.be/IMG/ pdf/EUDO-2009-Turkey-linked.pdf (describing this as a "fabricated umbrella identity).

${ }^{27}$ Turkish Citizenship Law 2009, L. No. 5901, art. $44 \$ 1$, http://globalcit.eu/wp-content/plugins/rscas-database-eudo-gcit/? $\mathrm{p}=$ file\&appl=currentCitizenshipLaws\&f=TUR\%20Turkish\%20citizenship\%20law\%202009\%20\%28English\%29.pdf (Turk.) (providing a version of the English translation commissioned by the European Union Democracy Observatory of the law as it stood on May 29, 2009); İNCI ATAMAN-Figanmeşe, Privat- und prozessrechtliche Folgen der doppelten Staatsangehörigkeit nach turkischem Recht, [Private and Civil Procedural Effects of Dual Citizenship Under Turkish Law] in AUSWIRKUNGEN DER

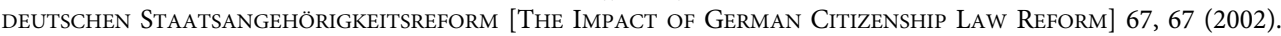

${ }^{28}$ Turkish Citizenship Law art. $13 \S 1$.
} 
[In the 1980s], given the sizeable number of Turkish immigrant workers in Western European countries intending to live with their dependents in those countries, it became necessary to introduce dual citizenship into Turkish law. Therefore, the Turkish population living abroad acted as a catalyst for the formation of citizenship policies for the period of 1980 to $2000 .^{29}$

To assist citizens wishing to naturalize in a country that requires renouncing their Turkish citizenship, Turkey developed two legal methods. The first was Article 13 which allowed Turks to easily reacquire Turkish citizenship whilst retaining their German or other foreign citizenship. After long-term residence in Germany, they naturalized there, renouncing their Turkish citizenship as required. Then, quietly, perhaps on the next trip back to Turkey, the newly naturalized Germans reacquired their Turkish citizenship. Because of the domestic exemption, individuals did not lose their German citizenship, and after 1981 were able to retain both. This procedure was "supported and encouraged by Turkish authorities and embassies."30

The second way in which the Turkish government assisted its citizens to acquire foreign citizenships was through a 1995 amendment to Turkish law creating an ingenious almostcitizenship which has been dubbed "citizenship light." 31 Known first as the "pink card" (pembe kart), changed in 2004 to the "blue card" (mavi kart) and available only to former Turkish citizens, it grants privileges not offered to other foreigners. These privileges include the rights to reside in Turkey, inherit, carry out all trades and professions, and buy and sell property.

Those who had been Turkish citizens by birth but lost it by obtaining a renunciation permit and their children transacted with them shall continue to enjoy, without prejudice to the provisions relating to national security and public order, the rights accorded to the Turkish citizens other than those, which are the responsibility of military service, the right to vote and to be elected, the right to be employed in public office and the right to import exempted vehicles and household goods, provided that their acquired rights relating to social security are saved and they are subject to the provisions of the relevant laws in the use of

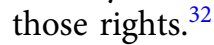

The drafter of the law that created the pink card told an interviewer that the status was created at the request of the head of the Hamburg branch of the "Turkish Communities in Germany" (Türkische Gemeinde in Deutschland) (TGD) to find a way Turks living in Germany could take on German citizenship without losing rights in Turkey. ${ }^{33}$

In practice, the pink/blue card has not been as helpful as expected. Users complain that the Turkish bureaucracy was not instructed about the existence of this privileged status and so the promised advantages never materialized. ${ }^{34}$ In addition, this status does not protect those who might own or inherit property in military security areas, ownership remains restricted to Turkish citizens. Turks have also expressed a lack of trust in the Turkish government to continue to offer the pink/blue card. ${ }^{35}$ For these and other reasons, Turks who naturalized in Germany will have preferred their own particular workaround: Renunciation of Turkish citizenship, then naturalization in Germany, followed by reacquisition of Turkish citizenship and preservation of German citizenship due to the domestic exemption.

\footnotetext{
${ }^{29}$ Bilgin Tiryakioğlu, Multiple Citizenship and its Consequences in Turkish Law, 3 ANKARA L. Rev. 1, 6 (2006).

${ }^{30}$ Kadirbeyoğlu, supra note 26, at 4.

${ }^{31}$ Ayşe CAĞLAR, "Citizenship Light": Transnational Ties, Multiple Rules of Membership, and the "Pink Card", in WorLds ON the Move: Globalization, Migration, and Cultural Security 273 (Jonathan Friedman \& Shalini Randeria eds., 2004).

${ }^{32}$ Turkish Citizenship Law art. $28 \$ 1$; see also CAĞLAR, supra note 31, at 279.

${ }^{33}$ Kadirbeyoğlu, supra note 26 , at 6 .

${ }^{34} I d$. at 7 .

${ }^{35}$ CAĞLAR, supra note 31 , at 286.
} 


\section{Germany's citizenship law revolution}

In 1999 the time was right, and indeed overdue, for Germany to reform its citizenship law. Societal perception that long-term immigrants were failing to integrate into German society and to naturalize as Germans was thought to be a problem with Turks particularly-and not only because they make up the single largest minority ethnic group. The Turks were seen as distinctive and problematic. They did not integrate well according to then Chancellor Helmut Kohl, who told Prime Minister Margaret Thatcher in 1982 that he wanted to halve the number of Turks living in Germany, as Germany could not assimilate the such a large number. ${ }^{36}$ Public discussion about integration was all directed at Turks-including the Bundestag debates on the proposed law and the German government's own pronouncements. To this day, German government websites discussing multiple citizenship contain cheery photographs of people displaying two passports-one is always German and the second one always Turkish. ${ }^{37}$

\section{The reforms of 1999}

On March 16, 1999, the bill that eventually became the new German Citizenship Law was introduced in the lower house, the Bundestag. Gerhard Schröder as Chancellor presided over a government in which his Social Democrats (SPD) were in coalition with the Green Party. ${ }^{38}$ The title of the bill was, "Draft of a Law to Reform Nationality Law" and the subtitle made the goal of the law clear: "Improvement of the integration of those foreigners living long term in the FRG and of their children through easing of the requirements for German citizenship." 39 The original proposal would have allowed dual, even multiple, citizenship. In the debate on the first reading of the bill, Germany's Minister of the Interior said clearly:

Of course, a thorough integration policy is not limited to reform of the citizenship law. But reform of the citizenship law is an important element of a comprehensive integration policy. Reform of citizenship law is even more than that: It is the nucleus of a comprehensive integration policy because integration-I am firmly convinced of this-can only succeed when through the acquisition of German citizenship citizens of foreign origin can have an equal participation in German community life. ${ }^{40}$

He pointed out a poorly-disguised prejudice against Turks that underlay many objections by the conservative Christian Democrat Union/Christian Social Union (CDU/CSU) to dual citizenship, using as an example the aristocrat Otto von Habsburg, who had served as a CDU/CSU Member of the European Parliament for over 20 years:

It is strange, that the CDU/CSU doesn't have a problem with the multiple citizenships of Otto von Habsburg but want to deny the retention of his previous citizenship to a citizen of

\footnotetext{
${ }^{36}$ Germany's Helmut Kohl “wanted half of Turks sent back," BBC (Aug. 1, 2013), https://www.bbc.com/news/world-europe23544311.

${ }^{37}$ See, e.g., Debatte über Aufhebung der Optionspflicht [Debate on the Cancellation of the Option Obligation] (July 3, 2014), http://www.bundestag.de/dokumente/textarchiv/2014/kw27_ak_optionspflicht/285946 (showing a striking graphic on the Bundestag's website, which appears to show a single passport that is both German and Turkish, may have confused some people into thinking that "Doppelpass," used as a shorthand for "dual citizenship," actually meant a single, double-nationality passport); see also Debatte über Aufhebung der Optionspflicht, DEUTSCHER BUndESTAG, https://www.bundestag.de/ dokumente/textarchiv/2014/staatsangehoerigkeit/281606.

${ }^{38}$ For details about the political wrangling that led to the eventual passage of the bill, see Marc M. Howard, The Causes and Consequences of Germany's New Citizenship Law, 17 Ger. Pol. 41, 48-51 (2008); Merih Anil, No More Foreigners? The Remaking of German Naturalization and Citizenship Law, 1990-2000, 29 DialeCtiCAL ANTHropology 453, 462-66 (2005).

${ }^{39}$ Gesetzentwurf [Draft Law], Deutscher BundestaG: DrucKSACHEN [BT] 14/533 http://dip21.bundestag.de/dip21/btd/ 14/005/1400533.pdf.

${ }^{40}$ Bundestag debate at 2318 (Mar. 19, 1999) (statement of Otto Schily) http://dip21.bundestag.de/dip21/btp/14/14028.pdf.
} 
Turkish origin, who has lived here for decades, does good work, pays his taxes and social security, leads a law-abiding life and enriches our society culturally as well. ${ }^{41}$

At the second reading of the bill, Minister Schily stated that he hoped that multiple citizenship could be avoided but "[f]or us, integration is more important than the avoidance of multiple citizenships." ${ }^{42}$ However, the leader of the Free Democrats (FDP) contingent in the Bundestag wanted to see a demonstration of exclusive loyalty on the part of the would-be German, however:

The state's offer of integration must be met with an active decision for integration with this state.

This is true also for the offer to adults of naturalization. A person who wants to become German should demonstrate this through the renunciation of his former citizenship. The German passport is not just any old paper that one would like to have in addition to others, rather it requires a conscious turning toward the German state ... When a person has lived in Germany for 20, 30 years, he knows the country, and I think it is fair to require of him a conscious decision in favor of the country where he lives. ${ }^{43}$

In a plea both for multiple citizenship and for a waiver for older immigrants from the German language requirement that the bill would introduce, a Turkish-origin representative from the Green Party then gave an example of a constituent who wanted to retain his Turkish passport to ensure that he could be buried in Turkey, with his ancestors.

[Özdemir] This man isn't trying to get the ability to vote in two places, nor does he care about some other advantage, it's a question of simple human things. Would it be such a disaster if we were generous in these cases, to a small group of people, who came to us in 1973 or before under the labor agreement?

[Westerwelle] I'm not talking about a disaster here, I'm talking about whether, as a political matter, we want to require that people who have lived in Germany a long time make a conscious decision in favor of the country where they live ... You and I have different approaches: For you, integration policy is just the state's offer of integration, for us integration policy is the offer by the state of integration and the decision by the individual to accept the offer. ${ }^{44}$

On May 7, 1999, the Bundestag passed the Citizenship Law with the votes of the SPD/Greens and the FDP. Approval by the upper house - the Bundesrat-followed on May 21, 1999, and the law became effective on January $1,2000 .^{45}$

Some commentators called the 1999 law a "revolution," in that German citizenship was for the first time made available not only through descent but also by birth in the country (jus soli) and provision was made for previous citizenship to be retained when naturalizing in Germany. ${ }^{46}$ The new changes in the law included that children born in Germany on or after January 1, 2000 would

\footnotetext{
${ }^{41}$ Id.; Otto von Habsburg Obituary, THE GUARDIAN (July 4, 2011), https://www.theguardian.com/world/2011/jul/04/ottovon-habsburg-obituary (stating Von Habsburg, son of the last emperor of the Austro-Hungarian Empire, held citizenship in Germany, Austria, Hungary and the Czech Republic).

${ }^{42}$ Bundestag debate at 3423 (May 7, 1999) (statement of Otto Schily) http://dip21.bundestag.de/dip21/btp/14/14028.pdf.

${ }^{43} I d$. at 3436 (statement of Rep. Guido Westerwelle).

${ }^{44}$ Id. at 3437.

${ }^{45}$ Stenographischer Bericht 40 Sitzung [40 th Report, Results of the Vote], DeUTSCHER BundeSTAG: DRUCKSACHEN [BT] 14/ 3461, http://dip21.bundestag.de/dip21/btp/14/14040.pdf; see also Kay Hailbronner \& Anuscheh Farahat, Country Report: Germany, EUDO CitIZENSHIP OBSERVATORY (2015) at 6-7, http://cadmus.eui.eu/bitstream/handle/1814/34478/EUDO_ CIT_2015_02-Germany.pdf?sequence=1.
} 
be German citizens if, at the time of their birth, at least one parent had been customarily resident in Germany for eight years and had the permanent right to remain in the country. ${ }^{47}$ If the child acquired two or more citizenships at birth, he was required by his twenty-third birthday to either choose German citizenship and give up the other(s), or to lose German citizenship. ${ }^{48}$ This provision was known as the "Duty to Choose" (Optionspflicht). The acceptance of multiple citizenship was very limited, for persons naturalizing as Germans were still required to give up their prior citizenship except if: (1) That prior citizenship was from the EU or Switzerland, (2) the prior citizenship could not be relinquished without "undue difficulty or expense," or (3) their prior country of citizenship did not permit them to renounce their citizenship. ${ }^{49}$

The new law also changed the criteria for naturalization. The period of residence required to naturalize was reduced from fifteen to eight years. But other aspects of the 1999 law actually made it harder to naturalize, by requiring proof of ability to support oneself, and introducing integration-oriented requirements such as an oath of loyalty to the constitution and a German language competence test. The latter proved particularly difficult for the earliest Turkish arrivals, many of whom were by then in late middle age. They had not been encouraged or supported in learning German when they arrived in the country, since they were supposedly "guest workers" (Gastarbeiter) who would be leaving soon. ${ }^{50}$ These changes in the naturalization requirements - which were thought by the German government to be liberalizing — were met with a lack of interest on the part of Turkish heritage residents. Even after years of publicity and urging by the German government, the rate at which eligible Turkish residents choose to naturalize languishes at or below two percent per year. ${ }^{51}$

Although the new law received much publicity as a break with Germany's jus sanguinis past, one provision was not so well publicized: The elimination of the "domestic exemption" that had allowed Germans living in Germany to acquire a second citizenship, or reacquire their previous citizenship, while retaining German citizenship. The new law provided that in the absence of prior "permission to retain" (Beibehaltungsgenehmigung), a German citizen's acquisition of a second citizenship - other than in certain European countries-automatically revoked his German citizenship. This created problems for the German and Turkish governments, as apparently Turkish authorities had continued to allow their former citizens to reacquire Turkish citizenship after naturalizing in Germany and had not reported this to German authorities so that the loss of German citizenship could be recorded.

On December 14, 2004, the opposition parties introduced in the Bundestag a resolution entitled "Don't Hide the Problems with Turkey." ${ }^{2}$ That resolution would have declared it to be the sense of the Bundestag that the federal government should not vote in the European Council to open accession talks with Turkey unless certain problems were discussed and Turkey committed to contributing to their solution.

\footnotetext{
${ }^{46}$ See, e.g., H.-P. MANSEL, Zur Reform des Staatsangehörigkeitsrechts 2000 [Regarding the 2000 Reform of the Citizenship

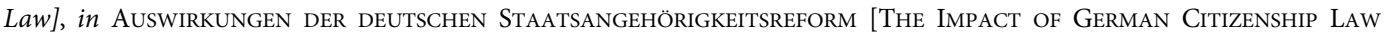
REFORM] 9, 9 (2002).

${ }^{47} \mathrm{STaG} \$ 4$, g 3.

${ }^{48} \mathrm{STaG} \$ 29$.

${ }^{49}$ Simon Green, Much Ado About Not-Very-Much? Assessing Ten Years of German Citizenship Reform, 16 CITIZENSHIP STUD. 173, 181 (2012).

${ }^{50}$ Helmut RitTstieg, Staatsangehörigkeit, deutsche Leitkultur und die deutsch-türkischen Beziehungen [Citizenship, German, Leading Culture and German-Turkish Relations] in AUSWIRKUNGEN DER DEUTSCHEN STAATSANGEHÖRIGKEITSREFORM> [The Impact of German Citizenship LAW ReForm] 13, 14 (2002).

${ }^{51}$ Einbürgerungen [Naturalizations], STATISTISCHES BUnDESAMT, https://www.destatis.de/DE/PresseService/Presse/ Pressemitteilungen/2017/06/PD17_195_12511.html (In the most recent figures available, between 2009 and 2016, the highest rate was $2.3 \%$ (2012) and the lowest was $1.2 \%(2016))$.

${ }^{52}$ Deutscher Bundestag: Drucksache [BT] 15/4496, http://dipbt.bundestag.de/dip21/btd/15/044/1504496.pdf; the "report" to which the resolution refers was Verbotener Doppelpass [Forbidden dual citizenship], Focus (Sept. 27, 2004), http://www. focus.de/politik/deutschland/diplomatenstreit-verbotener-doppelpass_aid_202183.html.
} 
Turkey must accept German nationality law; the German government must take steps to ensure that the practice of re-naturalizing contrary to law is stopped.

A Turkish citizen who wants German citizenship must, in the course of naturalization, absolutely renounce Turkish citizenship... [r]ecently it was reported that in the words of the Turkish Foreign Minister Ugur Ziyal, “40,000 to 50,000 ... maybe more” Turkish citizens are illegally in possession of a German passport in a breach of these rules of German citizenship, and that this has occurred with the help of the Turkish government. By decree of 10 September 2001 the Turkish government directed all offices to manipulate the register extracts demanded by the German government and in this fashion conceal from German officials the reacquisition of Turkish citizenship ... The federal government should make it clear to the Turkish government that such behavior does not result in productive relations between countries. Also, it cannot be solved merely by the revocation of the decree.

During the debate on this resolution, the ruling coalition admitted that approximately 48,000 Turks had lost their German citizenship after January 1, 2000 by reacquiring Turkish citizenship after the domestic exemption was revoked. Those persons would need to re-naturalize in Germany. ${ }^{53}$ Of even greater concern to the CDU/CSU would have been that between January 1, 2000 and the end of 2004 there were numerous elections in Germany-sixteen elections for the legislatures of the Länder, one for the Bundestag and one for the European Parliamentin which these non-citizens could have voted, and Turkish Germans vote overwhelmingly for parties other than the CDU/CSU. ${ }^{54}$

\section{The Turkish response}

Once the news of the elimination of the domestic exception trickled through to the population and to the Turkish authorities, there was a precipitous drop in the number of Turks who sought formal release from their citizenship in order to naturalize abroad. In 2000, the number of persons seeking permission to exit was 12,635, which increased in 2001 to 27,576. By 2004, the number dropped to a mere $1,828 .{ }^{55}$ Turkish naturalizations in Germany peaked in 1999 at over 100,000 , then declined to 19,695 in 2015 , and just 16,290 in $2016 .^{56}$

Turkey could have taken on the challenge of the new German law in a number of ways. It could have better promoted the pink/blue card. It could have eliminated all remaining restrictions on inheritance, social security, and property ownership for former Turkish citizens. Or it could have simply prohibited the renunciation of Turkish citizenship, thereby bringing Turks within the exception to the German renunciation requirement. But when Turkey's citizenship law was most recently amended, in 2009, not one of these changes was made.

Turkish failure to make their citizenship non-renounceable is puzzling because it would solve the dual citizenship problem and allow Turks to easily take on German citizenship and fully integrate into German society. The reason cannot be, as has been posited, that it is too difficult politically to change Turkish citizenship law to accommodate the Turkish diaspora. ${ }^{57}$ As we have

\footnotetext{
${ }^{53}$ Bundestag debate at 14281 (Jan. 21, 2005) (statement of Ute Vogt, Parliamentary Secretary of the Ministry of the Interior), http://dip21.bundestag.de/dip21/btp/15/15152.pdf.

${ }^{54}$ Şener Aktürk, The Turkish Minority in German Politics: Trends, Diversification of Representation, and Policy Implications, 12 INSIGHT TURK. 65, 69 (2010); Schwarz, rot, grün - welche Parteien bevorzugen Zuwanderer? [Black, red, green - which parties do immigrants prefer?], SACHVERSTÄNDIGENRAT DEUTSCHER STIFTUNGEN FÜR INTEGRATION UND MIGRATION [COUnCIL OF EXPERTs, German FOundations FOR InTEgration AND Migration] at 28 (2016) https://www.svrmigration.de/wp-content/uploads/2016/11/PB_Parteipraeferenzen.pdf (70\% of Turkish heritage immigrants prefer SPD, $13 \%$ Greens, compared to $6 \%$ CSU/CSU).

${ }^{55}$ Kadirbeyoğlu, supra note 26 , at 15.

${ }^{56}$ Einbürgerungen, supra note 51 , at $13,19-42$.

${ }^{57}$ Aktürk, supra note 54 , at 75 .
} 
seen previously, the Turkish government has repeatedly created new Turkish laws in response to changes in German citizenship law-for example, the pink/blue card, and the provision for easy reacquisition of Turkish citizenship after the renunciation required for naturalization in Germany.

The Turkish government has accommodated its citizens' desires to naturalize in their countries of residence because, "the lobbying potential of migrants living in European countries has been seen as an asset by governments in Turkey." ${ }^{58}$ Since coming to power in 2002, the Justice and Development Party (Adalet ve Kalkınma Partısı) (AK Parti) has shown an increasing interest in the Turkish diaspora, particularly those living in Germany. In 2010, a government department was set up to deal with Turks abroad, the "Presidency for Turks Abroad and Related Communities" (Yurtdışı Türkler ve Akraba Topluluklar Başkanlığı). In 2012, its Chairman stated the office's goals the following:

In its work with the citizens living overseas, the Presidency encourages them to actively participate in public life in their respective host countries while preserving their own culture and supports all efforts in that direction. The Presidency is also responsible for ensuring that Turkish citizens benefit equally from legal rights in the countries they reside in ... [i]n the future, the Presidency will continue prioritizing efforts to help Turkish citizens become prominent forces in the countries they reside in, work towards ensuring their equal participation in public life as well as foster a common consciousness amongst them. ${ }^{59}$

In an address in 2011, then Prime Minister Recip Tayyip Erdoğan, appearing in Düsseldorf, controversially urged his fellow Turks to "integrate" into German society, but not to "assimilate," and to teach their children Turkish first, German second. ${ }^{60}$ Turks living in Germany-who may feel that German politicians do not take their concerns seriously-have welcomed Erdoğan as the champion of the Turkish diaspora. ${ }^{61}$

One step taken by the Turkish government to bind the diaspora to the motherland-even while encouraging Turkish citizens to take part in politics in their countries of residence-was to change Turkish election law. In 2008, that law was amended to allow Turkish citizens abroad to vote in referenda and presidential elections, the result of a multi-decade campaign by Turks abroad for this right. ${ }^{62}$ Previously, Turks living abroad could vote only if they returned to Turkey for election day, but the 2008 law permitted votes to be cast in a number of different ways: By post, electronically, at the Turkish border, or in Turkish embassies and consulates abroad. The provision for postal votes was struck down by the Constitutional Court, tamper-proof electronic voting proved infeasible, and there were years of delay in negotiating agreements with other countries to allow voting at Turkish diplomatic missions. Finally, in time for the August 2014 presidential election, Turks were able to vote from their foreign countries of residence. This had the effect of exporting the political Sturm und Drang of the Turkish homeland to host countries-even though Article 94 of the Turkish general election law prohibits campaigning outside the borders of Turkey. ${ }^{63}$

\footnotetext{
${ }^{58}$ Kadirbeyoğlu, supra note 26, at 4 (citing Turkish Parliamentary Minutes from June 7, 1995).

${ }^{59}$ Kemal Yurtnaç, Turkey's New Horizon: Turks Abroad and Related Communities, 3 CENTER fOR STRATEGIC ReSEARCH 6-7, 10 (Oct. 2012), http://sam.gov.tr/wp-content/uploads/2012/10/SAM_paper_ing_03.pdf.

${ }^{60}$ You are Part of Germany, but also Part of our Great Turkey, DER SPIEGEL (Feb. 28, 2011), http://www.spiegel.de/ international/europe/erdogan-urges-turks-not-to-assimilate-you-are-part-of-germany-but-also-part-of-our-great-turkey-a748070.html.

${ }^{61}$ Pastor und Sultan, DER SPIEGEL (May 5, 2014), http://www.spiegel.de/spiegel/print/d-126830884.html.

${ }^{62}$ The history of the effort can be found in Zeynep Şahin-Mencütek \& M. Murat Erdoğan, The Implementation of Voting from Abroad: Evidence from the 2014 Turkish Presidential Election, 54 INT'L MigRATION 173 (2015).

${ }^{63}$ Shabtai Gold, et al., Turkish Law Prohibits Campaigning Abroad-as Row with Europe Deepens, DeUTSCHE PRESSE AgENTUR (Mar. 9, 2017), http://www.dpa-international.com/topic/turkish-law-prohibits-campaigning-abroad-row-europedeepens-170309-99-595734.
} 
This outreach to the diaspora is part of the new AK Parti-encouraged vision of Turkey as a strong country, able to protect its own both at home and abroad. In a 2003 address to migrants, then Prime Minister Erdoğan stated:

Today, Turkey has reached the situation of being powerful, ambitious, having high goals. Turkey sets the agenda, instead of its agenda being set by others. Turkey should be taken into account in considering world affairs ... [a] powerful country protects her citizens abroad, kin communities and brothers. ${ }^{64}$

The economic success of Turkey in the first decade of AK Parti rule, from 2002 to 2012, allowed it to partially redress the asymmetry of power between itself and other countries, most particularly Germany. As the larger, richer country, Germany was previously able to determine the conditions Turks must accept to live in Germany, including the attempted prohibition of dual citizenship. However, during the AK Parti period, Turkey has challenged this inequality and attempted to redefine bilateral relations. ${ }^{65}$

\section{More changes by the Germans}

The 1999 German law, although "revolutionary," was flawed from the compromises that were necessary to secure its passage. Further amendments in 2004 and 2007 resolved various technical issues and standardized both the level of German language competence required and the test regarding German life and society, which, until then, differed depending on the German Land in which the applicant lived. ${ }^{66}$

These relatively small changes, however, did nothing to ease the prohibition of multiple citizenships for those persons from countries outside the EU and Switzerland. The "Duty to Choose" (Optionspflicht) that gave temporary dual citizenship under the 1999 law was quickly renamed "Pressure to Choose" (Optionszwang) by those unhappy with the compromise. Between January 1, 2000 and December 31, 2013, nearly half-a-million German-born children of foreign parents had temporarily acquired German citizenship, building up a substantial population of young people who were soon going to be faced with the difficult decision between their German citizenship and that of their familial homeland. ${ }^{67}$

Effective December 20, 2014, the Optionspflicht was almost done away with. Now dual citizens born in Germany may retain their dual citizenship permanently, if by their twenty-first birthday they have either lived eight years in Germany, attended school there for six years, or graduated from a German school or training program. ${ }^{6}$ Dual citizenship is, however, still proscribed for persons born outside of Germany, unless they fall into one of the previously-granted exemptions: EU and Swiss citizens, persons who cannot renounce citizenship, or for whom it would be a substantial problem. The head of the TGD pronounced the law to be "a bitter disappointment"

\footnotetext{
${ }^{64}$ Şahin-Mencütek \& Erdoğan, supra note 62, at 181 (quoting Prime Minister Erdoğan).

${ }^{65} \mathrm{Id}$.

${ }^{66}$ Green, supra note 49 , at 178 .

${ }^{67}$ DeUTSCHER BundeSTAG: DrUCKSACHE 18/10788, http://dip21.bundestag.de/dip21/btd/18/107/1810788.pdf (answering a parliamentary question).

${ }^{68}$ Bericht der Beauftragten der Bundesregierung für Migration, Flüchtlinge und Integration 42 [1 $1^{\text {th }}$ Report of the Federal Government Commissioner for Migration, Refugees and Integration - Participation, Equal Opportunities and Legal Development in the Immigration Society Germany] (Dec. 2016), https://www. bundesregierung.de/resource/blob/975292/729998/fdcd6fab942558386be0d47d9add51bb/11-lagebericht-09-12-2016-down load-ba-ib-data.pdf?download=1 [hereinafter BERICHT DER BEAUFTRAGTEN].
} 
as it made no provision for the older generation: "Those of the first generation who have worked here for decades and made Germany their home go empty-handed." ${ }^{\prime \prime}$

Although now more than fifty percent of all naturalizations in Germany are to people who retain their previous citizenship, German law continues to require exceptional measures of many who wish to hold multiple citizenships. ${ }^{70}$ The privilege of multiple citizenships is reserved mainly for native Europeans, to the detriment of the largest immigrant group, the Turks. ${ }^{71}$

In her 2016 report, the German Commissioner for Migration, Refugees and Integrationherself a German-born naturalized Turk-has called for an end to the conditions on citizenship granted to children born in Germany and for the full acceptance of all multiple citizenships. ${ }^{72}$ This is a very raw subject with Conservatives. As recently as December 2016, the CDU party conference called for the end of multiple citizenship and a return to the "Duty to Choose." ${ }^{3}$ The abolition of multiple citizenship was a plank in the CDU manifesto for the September 24, 2017 Bundestag elections. ${ }^{74}$ This is in spite of the fact that out of Germany's population of 81.4 million, over 1.6 million persons currently hold a second citizenship in addition to German, and fifteen percent of those are Turkish citizens. ${ }^{75}$

It has been shown that the requirement to give up their Turkish citizenship is the primary reason Turks have been prevented from naturalizing. The risk of giving up rights to inheritance and property:

May be perceived as too high a price to pay by many people who already feel cut off from their families. Of course, there are also cultural and patriotic sentiments that are difficult to come to grips with, and apparently not many foreigners are willing to abandon their current citizenship altogether. This sentiment may be especially pronounced for citizens of countries - like Turkey_that primarily think of citizenship along blood lines. ${ }^{76}$

\footnotetext{
${ }^{69}$ Germany's Turkish Community Says Let Down by Coalition Deal on Dual Citizenship, Hürriyet Daily News (Nov. 27, 2013), http://www.hurriyetdailynews.com/germanys-turkish-community-says-let-down-by-coalition-deal-on-dual-citizen ship.aspx?pageID $=238 \& \mathrm{nID}=58654 \&$ NewsCat ID $=351$.

${ }^{70}$ Pusch, supra note 23, at 4-5; Karen Schönwälder \& Triadafilos Triadafilopoulous, A Bridge or Barrier to Incorporation? Germany's 1999 Citizenship Reform in Critical Perspective, 101 Ger. POL. \& Soc'Y 52, 55 (2012); Bericht der Beauftragten, supra note 68, at 40 (stating that in 2015 the figure was $54.2 \%$ ).

${ }^{71}$ The TGD has made the recognition of multiple citizenships one of its major goals, so far unsuccessfully. For a history of its efforts in this regard, see Politische Partizipation, TÜRKISCHE GEMEINDE in Deutschland, http://www.tgd.de/category/themen/ politische-partizipation/.

${ }^{72}$ Bericht Der Beauftragten, supra note 68, at 43; Biography of Commissioner Aydan Özoğuz and Deputy Head of the $S P D$, https://www.integrationsbeauftragte.de/Webs/IB/DE/AmtUndPerson/Lebenslauf/lebenslauf_node.html.

${ }^{73}$ Germany's CDU Votes to Limit Immigrants' Rights to Dual Citizenship, Financial Times (Dec. 7, 2016), https://www.ft. com/content/557a5ec0-bc7b-11e6-8b45-b8b81dd5d080; Zurück zur Optionspflicht? [Back to the Duty to Choose?], Die Zeit (Dec. 8, 2016), http://www.zeit.de/politik/deutschland/2016-12/doppelte-staatsbuergerschaft-cdu-optionspflicht-faq.

${ }^{74}$ Regierungsprogramm, [Program for Government] 74 (2017), https://www.cdu.de/system/tdf/media/dokumente/170703 regierungsprogramm2017.pdf?file=1\&type=field_collection_item\&id=9932; Unser Regierungsprogramm für Deutschland, [Program for Government] 88 (2017), https://www.spd.de/fileadmin/Dokumente/Bundesparteitag_2017/Es_ist_Zeit_ fuer_mehr_Gerechtigkeit-Unser_Regierungsprogramm.pdf (supporting multiple citizenship for both children born in Germany and for persons naturalizing as German); "Wahlprogramm” [Election Programme] (2017), https://www.fdp.de/ wp-modul/btw17-wp-a-81 (suggesting multiple citizenship for all persons on an equal basis, regardless of their country of first nationality, but ending with the third generation any dual citizenship based on heritage); "Grundsatzprogramm," [Basic Principles] 65 (2017), http://alternativefuer.de/wp-content/uploads/sites/7/2016/05/2016-06-27_afd-grundsatzpro gramm_web-version.pdf (suggesting an end to multiple citizenship for all but exceptional cases and revoking the 1999 law's introduction of jus soli).

${ }^{75}$ Migration, supra note 3, at 167 (Micro census of 2015 shows 246,000 dual citizens Turkish/German. The Federal Office of Statistics says that the actual figure is probably higher, somewhere between 246,000 and the 530,000 counted in the 2011 census).

${ }^{76}$ Howard, supra note 38 , at 56 .
} 
The tide of history is against countries such as Germany which penalize multiple citizenships. This shift can be demonstrated on a macro scale by the 1997 European Convention on Nationality which, although remaining neutral on the issue of multiple nationality, does not discourage it. $^{77}$ This is a striking change of position as compared to the 1963 Convention on that subject, which required the loss of citizenship for European citizens naturalizing in another treaty country: "Nationals of the Contracting Parties who are of full age and who acquire of their own free will, by means of naturalization, option or recovery, the nationality of another Party shall lose their former nationality. They shall not be authorized to retain their former nationality." 78 The current German position is now completely different from that of the 1963 Convention-applicants from other "Contracting Parties" are automatically allowed to keep their first citizenship.

\section{Turks vote in Germany-in Turkish elections}

In the June 2015 Turkish election, Turks voted from a total of fifty-four different countries. ${ }^{79}$ The AK Parti has been rewarded for its efforts on behalf of expatriates, consistently winning their votes in proportions exceeding those realized in the motherland. ${ }^{80}$

The largest concentration of expatriate Turks is to be found in Germany, and it has been in Germany that the problems with foreign voting have been the most pronounced. Almost 40,000 people gathered in Cologne for a pro-Erdoğan rally after the July 2016 attempted coup, prompting Chancellor Angela Merkel to admonish German-resident Turks that, "we expect them to develop a high degree of loyalty to our country." 11 The run-up to the April 18, 2017 Turkish referendum on constitutional change memorably produced strife when Turkish government representatives were refused permission to hold rallies in Germany. ${ }^{82}$

It was not only the Turkish electioneering that provoked debate in Germany, but also the result of that constitutional referendum election, in which sixty-three percent of German-resident Turks voted for the proposed changes, as compared to just fifty-one percent in the total vote. This did nothing to reassure nervous German voters that the Turks who they were inviting to become citizens actually share the beliefs in the rule of law and constitutional government that they would swear to in their naturalization oath. Apparently without irony, German politicians from the ascendant right-wing "Alternative for Germany" (Alternative für Deutschland), invited the Turks who were in favor of authoritarianism to return to their own country where they could enjoy it all they wanted. ${ }^{83}$ Turkish journalist Can Dündar, living in exile in Germany,

\footnotetext{
${ }^{77}$ See Convention on Nationality, supra note 10, at (C 5) 14 (stating that member states "shall allow" multiple nationality where it is acquired automatically through birth or marriage).

${ }^{78}$ Convention on the Reduction of Cases of Multiple Nationality and Military Obligations in Cases of Multiple Nationality, Mar. 23, 1963 O. J. pmbl. \& (C 1) 1, § 1, https://rm.coe.int/168006b659.

${ }^{79}$ Zeynep Kadirbeyoğlu \& Asli Okyay, Turkey: Voting from abroad in 2015 general elections, GLOBALCIT (Aug. 6, 2015), http://globalcit.eu/voting-from-abroad-in-turkey-s-general-elections-2015/.

${ }^{80}$ See Kritik an Doppelpass_das sind die Fakten [Critique of Dual Citizenship-Here are the Facts], Der SPIEGEL (Dec. 7, 2016), http://www.spiegel.de/politik/deutschland/doppelte-staatsbuergerschaft-und-doppelpass-das-sind-die-fakten-a-1124805. html (stating the results of the 2014 presidential election, where 59.7\% of Turkish voters in Germany voted for the AK Parti as opposed to just $49 \%$ in Turkey itself).

${ }^{81}$ Ben Knight, Angela Merkel calls for 'loyalty' from German Turks, DeutsCHE Welle (Aug. 23, 2016) http://www.dw.com/ en/angela-merkel-calls-for-loyalty-from-german-turks/a-19496043; Old Fault Lines, ThE ECONOMIST (Aug. 6, 2016), https:// www.economist.com/news/europe/21703296-tensions-rise-turkey-they-spill-over-germany-old-faultlines.

${ }^{82}$ Alissa J. Rubin, Erdogan Calls Dutch "Nazi Remnants” After Turkish Minister Is Barred, N.Y. Times (Mar. 11, 2017), https://www.nytimes.com/2017/03/11/world/europe/turkey-netherlands-ban-referendum.html?_r=0; Turkey's Erdogan says German leaders are enemies, BBC (Aug. 18, 2017), http://www.bbc.co.uk/news/world-europe-40973197 (stating Erdoğan has since returned the favor by labelling the CDU/CSU, SPD and the Greens all "enemies of Turkey" and urging Turkish heritage German citizens to vote for other parties).

${ }^{83}$ Justin Huggler, Senior German Politicians Call for Changes to Dual Citizenship Laws after German Turks Vote to Increase Erdogan's Powers, The Telegraph (Apr. 18, 2017), http://www.telegraph.co.uk/news/2017/04/18/senior-german-politicianscall-changes-dual-citizenship-laws/.
} 
explained the vote in terms of identity rather than ideology, saying that Turks voted pragmatically for a Turkish leader who offered them an identity that Germany could not or would not give them. ${ }^{84}$

\section{Pressure points and some solutions}

\section{Consular assistance}

There have been several recent high-profile cases in Turkey when German officials were prohibited from visiting dual German-Turkish citizens held in Turkish custody. Although seemingly harsh, the Turkish refusal of such visits is entirely consistent with international law. True, the Vienna Convention on Consular Relations, ratified by both Germany and Turkey, guarantees that consular officers "shall be free to communicate with nationals of the sending State and to have access to them" - consular officers have the right to visit their country's nationals in detention, to correspond with them, and to arrange for legal representation. ${ }^{85}$ This right, however, does not apply when the person is a citizen of the country in which he is being held.

The 1930 Hague Convention on Certain Questions Relating to the Conflict of Nationality Laws clearly provides that "[a] State may not afford diplomatic protection to one of its nationals against a State whose nationality such person also possesses." ${ }^{86}$ Although only a dozen countries have ratified the Convention-excluding both Germany and Turkey-the non-responsibility principle it contains appears to have merely codified existing customary international law which continues to be followed even by countries that never adopted the Convention. ${ }^{87}$ This principle is not widely understood; even the German Ministry of the Interior lists "consular protection while abroad" as one of the advantages of naturalizing in Germany, without mentioning that this protection is not available to a German dual citizen who travels to his other country of nationality. ${ }^{88}$

Among the best known of the recent arrestees is Deniz Yücel, a journalist for Die Welt and citizen of both Germany and Turkey, who was arrested on February 14, 2017 and held for over a year before charges were dropped. ${ }^{89}$ Meşale Tolu, also a German-Turkish journalist born in Germany, was arrested and thereafter denied German consular assistance for months, even though she gave up Turkish citizenship in $2007 .{ }^{90}$ The German press called them Erdoğan's hostages, claiming that the Turkish government was holding German citizens (three of them, including Tolu and the human rights campaigner Peter Steudtner, are uniquely German

\footnotetext{
${ }^{84}$ Meine Türkei \& Almanyadaki Türkler, Oylarını versinler!, ZeIT OnLINE, (Apr. 26, 2017), http://www.zeit.de/kultur/201704/verfassungsreferendum-tuerkei-deutsch-tuerken-meine-tuerkei-tuerkisch.

${ }^{85}$ Vienna Convention on Consular Relations art. 36, Apr. 24, 1963, 8638 U.N.T.S. 262, https://reaties.un.org/doc/ Publication/UNTS/Volume\%20596/volume-596-I-8638-English.pdf.

${ }^{86}$ Hague Convention on Certain Questions Relating to the Conflict of Nationality Laws art. 4, Apr. 12, 1930, 179 U.N.T.S. 115, https://treaties.un.org/pages/LONViewDetails.aspx?src=LON\&id=516\&chapter=30\&clang=_en.

${ }^{87}$ Craig Forcese, The Capacity to Protect: Diplomatic Protection of Dual Nationals in the “War on Terror", 17 EUR. J. OF INT'L L. 369, 385, note 80 (2006) (collecting authorities).

${ }^{88}$ Einbürgerung [Naturalization], BUNDESMINISTERIUM DES INNERN, FÜR BAU UND HeIMAT [The FEDERAL MiNISTRY OF THE INTERIOR, FOR CONSTRUCTION AND HOME], http://www.bmi.bund.de/DE/Themen/Migration-Integration/Einbuer gerung/einbuergerung_node.html (last visited Jan. 16, 2018).

${ }^{89}$ Andrea Shalal \& Ece Toksabay, Germany summons Turkish ambassador, seeks release of jailed journalist, REUTERS (Feb. 28, 2017), http://uk.reuters.com/article/uk-turkey-security-germany-journalist-idUKKBN1662FM; Journalist for German newspaper arrested in Turkey, THE GUARDIAN (Feb. 27, 2017), https://www.theguardian.com/world/2017/feb/27/ journalist-for-german-newspaper-arrested-in-turkey; Deniz Yücel auf dem Weg zum Flughafen [Deniz Yücel on his way to the airport] SPIEGEL ONLINE (Feb. 18, 2018) http://www.spiegel.de/politik/ausland/deniz-yuecel-kommt-frei-a1193864.html.

${ }^{90}$ Imprisoned German national in Turkey receives consular visit, DeUTSCHE WeLLE (June 2, 2017), http://www.dw.com/en/ imprisoned-german-national-in-turkey-receives-consular-visit/a-39098071; German journalist Mesale Tolu Arrives Home after Turkey Lifts Travel Ban, DeuTsCHE Welle (Aug. 26, 2018), https://www.dw.com/en/german-journalist-mesale-toluarrives-home-after-turkey-lifts-travel-ban/a-45233372 (stating that she was released from detention in December 2017 but was not permitted to leave Turkey until August 2018; terror-related charges are still pending).
} 
citizens) $)^{91}$ for possible exchange against the return to Turkey of high-ranking asylum seekers. According to German sources, President Erdoğan told the German Foreign Minister that he would release Deniz Yücelin exchange for the return of two Turkish generals who sought asylum in Germany after the 2016 coup attempt. President Erdoğan is quoted as having told a German representative on May 30, 2017, “[i]f you don't help us by turning these people over, then you must [realize] that in the future you are not going to get back from us those people that you want." 92

Germany and Turkey should agree that as between their two countries they will allow full access to consular assistance from the other country of citizenship. The imposition on Turkey - that is, the German intrusion into Turkish criminal proceedings-will be relatively small, for even now there are only fifty-five German citizens being held by Turkish authorities, with twelve of these cases being described as "political." 93 In exchange, Turkey would gain the ability to visit dual citizens in German prisons and be able to demonstrate yet another way in which it is a big, strong country that is able to take care of its citizens, wherever they may live.

\section{The Germans and multiple citizenship}

German law must face up to German reality and allow multiple citizenship. Only then will the stagnant naturalization rates begin to rise. This is not a "Turkish problem," it is a widespread problem for citizens of all nationalities in Germany other than those from the EU and Switzerland. In 2015 only $1.3 \%$ of all foreigners in the FRG naturalized, one of the three lowest rates in twenty-five years, and exactly half the rate in the rest of the EU. ${ }^{94}$ As stated by the office of Migration, Refugees and Integration:

For the Commissioner, in view of the continuing low naturalization rate, the general acceptance of multiple citizenships in naturalization cases continues to be a goal toward which to strive. Holding fast to the principle of the avoidance of multiple citizenships is ever less defensible in naturalization cases, given that already more than half of all naturalizations (53.6\% in 2014) involve the retention of prior citizenship, that multiple citizenship has always been accepted for the children of binational families, and that after the latest amendment to the Option Law, multiple citizenships are permitted for the jus soli Germans who have grown up here. ${ }^{95}$

The Federal Supreme Administrative Court came to the same conclusion, finding that the changes introduced in 1999 and 2004 show that the legislative branch of the government "now lays less weight upon the avoidance of dual or multiple citizenship" than previously, and "the private interest of the individual in the establishment or retention of a dual or multiple citizenship is to be placed equal with the public interest of the avoidance of multiple citizenship." 96

\footnotetext{
${ }^{91}$ Deutsche Übersetzerin sitzt in der Türkei in Haft, [German Translator in Turkish Jail], ÖzGÜRÜZ (May 12, 2017), https:// ozguruz.org/de/2017/05/12/mesale-tolu/.

${ }^{92}$ Erdogans Geisel, [Erdogan's hostages], SPIEGEL OnLINE (June 2, 2017), http://www.spiegel.de/politik/ausland/mesale-toluin-der-tuerkei-wie-geht-es-der-deutschen-in-erdogan-haft-a-1150340.html; see also Andrea Thomas \& Anton Troianovski, Tensions Escalate Between Turkey and Germany, The Wall StreEt J. (July 27, 2017), https://www.wsj.com/articles/ tensions-escalate-between-germany-and-turkey-1501148072?mod=e2tweu; see also Sigmar Gabriel, Sevgili Türk hemşerilerim [My Dear Turkish Fellow Citizens], BILD (July 24, 2017), http://www.bild.de/politik/inland/sigmar-gabriel/ sevgili-tuerk-hemerilerim-52627324.bild.html.

${ }^{93}$ Deutschland verliert die Geduld mit der Türkei, [Germany loses patience with Turkey] FrANKFURTER ALLGEMEINE ZEITUNG (Sept. 3, 2017), http://www.faz.net/aktuell/wirtschaft/festgenommene-deutsche-deutschland-verliert-die-geduldmit-der-tuerkei-15181648.html.

${ }^{94}$ Bericht DER BeAuftragten, supra note 68 , at 430.

${ }^{95} \mathrm{Id}$. at 433.

${ }^{96}$ BVERwGE, Apr. 10, 2008, 5 C 28.07, http://www.bverwg.de/entscheidungen/pdf/100408U5C28.07.0.pdf.
} 


\section{E. Conclusion}

The Turkish-German relationship is of great importance to both countries. Germany is Turkey's largest trading partner, and people of Turkish heritage make up the largest immigrant group in Germany. Regardless of the harsh words exchanged recently, and the curtain of authoritarianism that is descending across Turkey, the countries will continue to be inextricably entwined. Even without the cooperation of the Turkish government, the German government can take steps to improve the integration of its Turkish heritage residents, including, but not limited to, making naturalization more attractive by permitting dual citizenship.

Cite this article: McFadden SW (2019). German citizenship law and the Turkish diaspora. German Law Journal 20, $72-88$. https://doi.org/10.1017/glj.2019.7 